PERO TABAK, M.Sc.

E-mail: ptabak@fpz.hr

Council of Postal Services

Martićeva 11, HR-10000 Zagreb, Republic of Croatia

SLOBODAN KAŠTELA, Ph.D.

E-mail: slobodan.kastela@fpz.hr

University of Zagreb,

Faculty of Transport and Traffic Sciences

Vukelićeva 4, HR-10000 Zagreb, Republic of Croatia
Transport Law

Review

Accepted: May 20, 2008

Approved: July 5, 2010

\title{
EU POSTAL DIRECTIVES AND CROATIAN REGULATORY FRAME
}

\begin{abstract}
The paper compares the EU Postal Directives (97/67/EZ and 2002/39/EZ) in a consolidated text and the respective parts of the Croatian legislative frame with the aim of harmonising the national postal system with EU. Both regulatory frames are presented, as well as objectives and scopes, types of postal services (particularly the universal ones), reserved area, necessary conditions governing the provision of services, tariff principles, insurance of market competition through transparency of financing and separation of the accounting system, desired quality of universal services, harmonisation of technical standards and obligations of national regulatory authorities. By presenting individual chapters of the Post Directives, some specific solutions of the Croatian regulatory framework have been indicated and uncertainties which result from the comparison analysis of the European Postal Directives and the Croatian legislation as well as the influence of these documents on the postal traffic technology.
\end{abstract}

\section{KEY WORDS}

EU Postal Directives, Croatian postal regulatory frame, universal services

\section{INTRODUCTION}

The negotiations regarding the accession of the Republic of Croatia to the European Union started formally on 3 October 2005. During the negotiations the conditions and methods of adopting and implementing the European Union legal heritage have been considered and determined (unified legal standards under the umbrella term acquis communautaire) into the Croatian legislation (1). Regarding the fact that postal traffic is a specific type of transport, this has come to the fore also in the process of negotiations about harmonising the national legislation with the EU acquis communautaire, so that the provision of post- al services is not included in Chapter 14 - Transport Policy (as other branches of Transport), but rather in Chapter 3 - Right of Establishment and Freedom to Provide Services.

The primary aim of the EU acquis communautaire in the area of postal activities is to use the regulatory framework to gradually and in a controlled manner open up the postal market for free market competition and to ensure continuous provision of universal postal services. The main source of acquis communautaire in the area of postal activities is the Postal Directive (97/67/EZ, and amendments 2002/39/EZ) as well as the decision brought by the European Court (EJC), and other acts that regulate the services of special government interest (SGEI - Services of General Economic Interest) and free market competition. At the beginning of 2008 also the third Postal Directive was adopted (Directive 2008/6/EZ) which will completely liberalise the European market of postal services at the beginning of 2011, i.e. 2013, and has therefore not been considered in this paper.

In 1991 when the Republic of Croatia gained independence, she took over from the former state the Postal Act, Telegraphic and Telephone Services and had implemented it until 1994, when the first Postal Act was brought (2). Nine years later, in 2003, the Croatian Parliament brought a new Postal Act (3). This Act was modified and amended in 2005 , primarily by regulating the conditions and methods of providing courier services. Based on the mentioned amendments of the Act, also the Regulations on general conditions for postal services have been amended (4), whereas other by-laws have not been modified nor amended. The new Postal Act is most likely to be expected by accession of Croatia into EU, i.e. with full liberalisation of the postal market.

In order to understand the regulations of the European Parliament and the European Union Council 
about the fully free market of all postal services it is necessary to be acquainted with the preambles (introductory statements) of all the Directives. They deal with the causes and consequences that can result from the changing of the Directives (e.g. on employment in the sector, social consequences, harmonisation of standards, and interoperability of operators), and they provide explanations of the reasons and expectations that result from the changing of Directives (e.g. about the unique common EU market, expectations of the users of universal as well as other postal services, and raising the quality of postal services). Since the entire contents of the mentioned Directives that precisely explain the reasons for the liberalisation of the market of all the postal services cannot be presented at one go, this paper will compare the contents of the EU Postal Directives with the respective Croatian regulations and their influence on the postal traffic technology.

\section{SUBJECT OF REGULATION}

The EU Postal Directives regulate in Article 1 six basic issues regarding the provision of postal services and these are:

- provision of universal postal services within the European Union,

- definition of services that may be reserved only for universal service providers, and the conditions which refer to the provision of non-reserved services,

- tariff principles and transparency of keeping accountancy for universal service providers,

- establishment of a quality standard for universal services and system of complaints in order to insure these standards,

- harmonisation of technical standards,

- establishment of an independent national regulatory authority.

The Croatian Postal Act regulates primarily the relation between the provider and the user of postal and courier services. It refers equally to international postal traffic if not otherwise regulated by the acts of the World Postal Union (WPU). Therefore, it should be noted that the WPU acts are not the only international sources that regulate the area of postal, and particularly not the courier services, since Croatia has signed also international agreements that are implemented directly on the postal and courier services (e.g. with the European Union and the World Trade Organisation (WTO)), as well as some other international agreements that have significant influence on some groups of postal and courier services (e.g. Montreal Convention for international air transport (5), and other conventions related to international forwarding and international road transport). Since the WPU acts regulate only the universal postal services, and not all postal and courier services, as mentioned in the Postal Act (Article 1), this indicates the lack of precision in legal terminology.

Furthermore, the definitions of key terms in the Postal Act (Article 2) have not been harmonised with the EU Postal Directives. There are, namely, significant differences both in the contents and in the quantitative difference in these terms. Moreover, the definitions of key terms are not identical, both in the legal acts and by-laws that regulate the postal system of the Republic of Croatia which makes the harmonisation of the Croatian regulatory framework with the European one additionally difficult.

\section{POSTAL SERVICES}

The EU Postal Directives define the postal services as services that include clearance, sorting, transport, and delivery of postal items. The Croatian Postal Act defines the postal services as services of receiving, transfer and delivery of postal items. By comparing the given definitions one may notice the differences, especially when single technological processes are considered as they are defined in Article 2 of Postal Directives, i.e. Postal Act. For instance, the term "transfer" has not been defined in the Postal Act and thus it is not clear to which technological process it refers, and "sorting" of postal items is not even mentioned in the definition of postal services, whereas the definition of the term "receiving" differs substantially from the defined term "clearance" from the Postal Directive.

This leads to the conclusion that there is certain entropy regarding the definitions of the basic term "postal services", especially when the mentioned elements are regarded as a unique process, i.e. postal service. Entropy is also increased when universal postal services are defined by additional criteria (availability, price, quality, etc.) and not exclusively by the technological description of the service which is used when defining other postal and courier services.

\subsection{Provision of universal postal services}

Article 3 of EU Postal Directives obligates the member countries (not the operators) that they must provide the right to universal services to all the users on their entire territory at affordable prices, and that they have to provide all the necessary measures in order to ensure sufficient density of post offices and other access points in compliance with the users' needs. Also, the member countries have to insure the performance of universal services at least five days a week. Only the national regulatory authority can decide on granting exemptions from these obligations. 
The Croatian Postal Act does not regulate the density of post offices and other access points, nor does it mention the conditions regarding the frequency of performing universal postal services (at least five times a week). This has been partly done by the by-law, i.e. Regulations on the Postal system of the public operator brought by the authorised Minister. This Act regulates only some of the mentioned obligations, and the Council of Postal Services, which is the national regulatory authority, regarding the activities related to universal services, has no significant authority. Especially worrying is the fact that public postal operator has the possibility of determining a narrower and a wider delivery area, i.e. there is no independent authority which really controls the frequency of performing the universal postal services.

The EU Postal Directive further regulates the minimum scope of universal services, and this is clearance, sorting, transport and delivery of letters up to $2 \mathrm{~kg}$, parcels up to $10 \mathrm{~kg}$, i.e. services that refer to the transfer of recommended and insured items. The Postal Act regulates the obligation of performing more universal postal services than regulated by EU Postal Directives. Thus, this Act obligates the national postal operator (NPO) to perform transfer of postal and telegraph orders, as well as special services, urgently and with return receipt. Also, the Regulations on General Conditions for performing of postal services have introduced the service of transfer of priority or non-priority items, regulated by Article 10 of the World Postal Convention, (Basic Services). However, the same Article of the World Postal Convention regulates that member states will implement one of the two classifications of postal items, either LC and AO (6), or priority and non-priority ones. Therefore, the question is whether the old classification ceased to be valid since the new one was introduced, mainly since no classifications have been directly mentioned in the Postal Act, whereas in the mentioned Regulations both classifications are provided. This issue is also very significant to determine the unit (minimally permitted) amount of postage in the reserved area.

Article 4 of the EU Postal Directives regulates the obligation of the member countries to provide universal services and to inform the Commission about the identity of one or several universal service providers. In this context, Croatia has defined in the Postal Act the Croatian Post (Hrvatska pošta - HP) as the public operator which is the provider of all the universal postal services, having the right and obligation to perform universal services on the entire Croatian territory. Because of this imposed obligation the public operator has been assigned the exclusive right of performing the reserved services in order to prepare within a certain time period for the future complete liberalisation of the postal service market.

\subsection{Services that may be reserved}

In the EU Postal Directives Chapter entitled Harmonisation of Services that may be reserved, the member states are allowed to implement the reserved area only for the universal service providers in order to avoid unfair financial burdening of unique performance of universal services in remote areas of the country. Phasing out of the monopoly has been forecast during the eleven years, by reducing the weight/ price limit reserved only for one (as a rule, national postal operator) or several universal service providers (if the member state determines thus voluntarily). The price - weight limits were reduced until now three times, and since 2006 the reserved area means prohibition of the transfer of postal items of up to 50 grams by other service providers. This prohibition is not applied if other providers charge the customer at least two and a half times higher price than the price for the published tariff for a letter of the first weight rate. It should be specially mentioned that the member states have been left the possibility of reserving the service of direct mail.

On the other hand, the Croatian Postal Act (Article 12) considers the reserved services to be "regardless of the contents of the post item and type of service, receiving, transfer and delivery of letter items from Article 10, Items 1 and 2, of mass up to $100 \mathrm{~g}$ in domestic and international incoming traffic," except if the "price is equal or higher than triple the price of the first mass rate of the fastest category." This makes it obvious that the Act reserves only for the public operator the transfer of letter items, as well as the transfer of letter items with special services, thus leaving the issue of the triple price of the first mass rate of the fastest category ambiguous. The fact should be mentioned that it is clear from the EU Postal Directives, and this is also confirmed by the European practice, that this refers to the price (maybe the higher one) for the transfer of ordinary letter weighing up to 20 grams. It is also obvious from the EU Postal Directives that since 2006 the mass of the reserved area has been reduced from 100 to 50 grams or the price has to be two and a half times higher than the published price for the transfer of a letter item of the first weight rate of the most expensive category.

Finally, the Act (Article 12, Item 3) mentions precisely the reserved postal services, regardless of the price limit. Therefore, the services of receiving, transfer and delivery of items of direct mail weighing up to 100 grams should be separated, for which the Postal Directives regulate that the services of direct mail transfer can be reserved with the same weight/price limits in order to insure performance of a unique obligation of providing universal services. Also, postal order traffic has been on the free market for quite a long time now, and the EU Postal Directives do not even mention it 
as a reserved service (even the public operator has a signed contract with other postal order service providers). Furthermore, the services of receiving, transfer and delivery of letters per administrative procedure weighing up to 100 grams are reserved services, whereas for court letters this has not been defined explicitly, although the EU Postal Directives (Article 8) left the possibility to member states to determine the universal service providers for the performance of these services, protecting thus certain interests of their own.

\subsubsection{Types of services and procedure for obtaining licences}

The EU Postal Directives classify postal services that are performed on the free market as:

- non-reserved services that do not belong to the group of universal services, and

- non-reserved services that belong to the group of universal services.

For the former group of postal services, the member states can introduce general authorisations in order to guarantee harmonisation with the basic requirements, whereas for the non-reserved services that belong to the group of universal services, the states may introduce the authorisation procedure, including also issuing of individual licences in order to guarantee the harmonisation with the basic requirements and to protect the universal services.

The Postal Act, Article 1 regulates postal and courier services, whereas distinguishing terminologically postal services, reserved services, universal services and courier services, and the text of the Act mentions also other postal services (Article 15, Item 2). This fundamental act of law does not fully unambiguously define where the services of transferring addressed and non-addressed print and the exchange of documents, i.e. the new, as well as the old services (express) related to the transfer of postal items belong to. On the other hand, Article 13 of the Act, regulates postal services performed on the free market (thus, these are all the services except for the reserved postal services) in which the providers of postal and courier services are allowed to perform certain postal services on a certain area, in compliance with the Act.

According to the Postal Act (Article 31) for the performance of universal postal services, the legal entity has to obtain a licence which should contain, among other things, a list of postal services that will be performed and in which area, and has to pay a concession and a percentage from the realised revenue. On the other hand, according to Article 37 of the Act, the right to perform courier and postal services that have not been included in the universal postal services, is acquired by the legal entity by submitting a written application including, among other things, a list of postal and courier services that will be performed and in which area, but without paying concessions or fees from the realised revenue. The term "list of postal services" which is mentioned together with the area of performing the services also in the procedure of applying for authorisations and submitting of applications is obviously the same, only that the procedure of submitting applications is simplified to the extent that the national regulatory authority is obliged to accept every complete application submitted by the provider.

The mentioned ambiguities regarding the type of service, including also the procedure of issuing licences and submitting applications, are based on the legal definitions which have not been harmonised with the EU Postal Directives. Our legislator, namely, based the definitions of postal and courier services, as well as of all the other services except the universal ones, on the technology of transfer of postal items. Thus, postal services mean receiving, transfer and delivery of postal items, whereas courier services have a somewhat more precise definition, but basically mean the same. The express services which also have a long postal tradition in accelerated receiving, transport and delivery of postal services, whose technology is a combination of courier (technology of receiving and delivery of items) and postal services (distribution of items through the network), have not been legally regulated. The most serious problem occurs when speaking of universal services since they have been defined by the Act as a "set of postal services of a certain quality which are available at affordable prices to all service users in an area for which the authorisation has been issued...", which means not exclusively by the technological description of the service. In other words, if the postal services are not offered in the same quality or not at an affordable price or are not available to all customers, then these are not universal but other postal services for which only an application is required in compliance with Article 13, i.e. 37 of the Postal Act.

\subsection{Tariff principles and transparency of keeping accountancy}

The tariff principles have been regulated by Articles 21 to 23 of the Postal Act which regulate the prices of postal and courier services. Regarding the protection of the reserved area by the price/weight limit, Article 21, Item 5 should be specially considered since this Item regulates that the postal service providers (which means not the courier service providers nor the universal service providers) can give a discount to the customers sending a larger volume of items, provided the same benefits are applied to all the customers under the same conditions. It is clear that the respective providers may offer a discount without any restrictions, if the costs are lower regarding the individual receipt. Also, the same Article regulates that the 
providers have to (but need not) use the franking machines, which means that there is no legal obligation of designating the amount of the paid postage for the respective service on the postal item, which means absence of efficient possibility of determining whether the reserved area has been violated.

Considering the prices of postal and courier services, the possible quantity discounts, i.e. "postage amounts", as stated in the Act, Article 11 of the EU Postal Directives should also be mentioned, which regulate the access of the customers and universal service providers to the public postal network which has to be transparent and non-discriminatory. Our public operator has not yet brought the act about the access to the public postal network, so that the customers themselves have no discounts according to the work (worksharing) that they possibly invest into the preparation for the clearance, sorting and transport to the point of delivery, and similar, thus reducing the costs of the requested services. This possibility is also considered in Article 12, Item 2 of the EU Postal Directives which, among other things claims that the tariffs have to take into consideration the inexistent costs compared to the actual costs of the entire service (regarding clearance, sorting, transport and delivery of items).

The tariff principles of universal services have been regulated by Item 1 Article 12 of the EU Postal Directives. This item contains a provision which obligates the member states to undertake measures in order to make sure that the tariffs of universal services are affordable and such that all the customers can use them, that the prices have to be based on the cost, that the tariffs have to be transparent and non-discriminatory. These provisions have also been included in the Postal Act. The EU Postal Directives provide the possibility to the member states to make decisions on the implementation of a "unique tariff on the entire territory", which means that it is possible to apply several tariffs. Without any prejudice of the justification of such a possibility, it should be mentioned that Spain has been applying two tariffs for quite a long time - the urban and the suburban one. Furthermore, the Directives state explicitly that the application of a unique tariff does not exclude the right of the universal service provider to sign individual agreements with the customers regarding prices, which means that the prices can be formed for the customers according to their needs or actual costs of the offered services.

\subsubsection{Transparency of financing and accountancy separation}

The EU Postal Directives in Article 9 leave the possibility to the member states, so as to protect the universal services, to establish a compensation fund for those universal service providers to whom the obligation of performing of these services represents unfair financial burden. The condition is for this fund to be managed by an independent authority regarding those who will use it. In this case the member states can condition for the issue of licences the obligation of the payment of financial contribution to this fund, and have to make sure that in establishing the compensation fund as well as in determining the amount of the financial contribution, the already mentioned principles of transparency, non-discrimination and proportionality are respected.

Article 32 of the Postal Act introduced the obligation of paying a fee for the licence (concession) and of the percentage of revenue realised from the universal services in the previous year, with the obligation being elaborated in more detail in Article 36 of the Act and in special Regulations brought by the authorised Minister i.e. Government. It is clear from the Act that all the universal service providers do not make the payment, i.e. that the public operator has been exempted from this obligation (both for the compensation and for the percentage of the revenue). According to the Act all the payments are carried out into the budget which is managed by the bodies of government administration that also own the public operator, and the method of distribution of this financial contribution has not been stipulated by the Government decision. Within the framework of this issue one should also mention the Regulations on the measures and criteria and the procedure of realising the rights to settle the costs of the public operator from the budget which regulates the procedure of settling the costs of HP in case of negative business operation regarding the reserved and universal services.

The member states have to undertake all the necessary measures to make sure that within two years from the date of coming into force of the first Directive the universal service provider keeps separated accounts within their internal accounting system at least for each of the service within the reserved area on the one hand, and for the non-reserved services on the other hand. For the non-reserved services the accounts have to clearly distinguish the services that are part of universal services and those that are not. Such internal accountancy systems are kept based on the consequently implemented and objectively verifiable principles of cost calculation. Further, there is mention of how national regulatory authority performs and monitors the separation of accountancy, and in a separate article all the universal service providers are obliged to submit their annual financial reports to an independent auditor and to publish them.

The Postal Act (Article 25) regulates the obligation of the public operator to insure from 1 January 2006 the accountancy keeping of the reserved postal services, for each service separately from the non-reserved postal services. Regarding non-reserved postal services they have to provide accountancy keeping of uni- 
versal postal services separately from the postal services that are not universal and courier services. Item 2 of this Article explicitly prohibits the public operator to subsidize postal services (probably also the courier services) that are performed on the free market from the revenues gained from the reserved services, not having at the same time stipulated any penalisation if the public operator does it nevertheless, like penalisations that have been stipulated for the public operator for not keeping separate accounting systems or for not allowing access to the public postal network and the similar.

\subsection{Quality of services and harmonisation of technical standards}

The EU Postal Directives (Articles 16 to 19) have introduced the obligation of the member states regarding the method of establishing and publishing the standardised norms regarding the required quality of universal services, which have to primarily focus on the time of postal items transfer, and proper performance and reliability of services. The member states are authorised to establish their norms for the services in internal traffic, in compliance with Article 17, provided they make sure that they are in compliance with those that have been planned to measure the quality of universal services within the Community, whereas the norms for the Inter-European traffic are brought by the European Parliament. Quality auditing has to be performed at least once a year by independent bodies that are in no relation to the universal service providers, according to the standardised norms brought by the European Standardisation authority according to the generally accepted principles of the profession. National regulatory authorities are responsible for the independent audits of the quality of universal services, and they have to undertake corrective activities in case of unsatisfactory results.

The Postal Act does not regulate the quality of performing universal services, but rather claims in Article 11 Item 2 that the public operator (but no other universal service providers) are obligated to ensure the level of quality of performing universal postal services stipulated by the Regulations on Services and Regulations on the Postal System. The latter Regulations regulates the public postal network, in other words, what the directives require in their Article 3 (density of post offices, their opening hours, narrower and wider area, etc.). Article 33 of the Regulations on Services regulates the quality of performing universal postal services, stipulating the measuring criteria for the quality of receiving and delivery of postal items, measuring criteria for the quality of postal items transfer, measuring the quality of postal items transfer and time limits for the transfer of postal items that are classified into three different categories.

Unfortunately, the standardised norms as Annex to EU Postal Directives have not been included in the Croatian regulations so that the methodology of measuring the quality of universal services is not clear, nor the methods for corrective measures that the regulatory authority is to undertake in case of unsatisfactory results. Article 20 of EU Postal Directives should be specially mentioned, speaking of the need to harmonise the technical standards, especially taking into consideration the customers' interests. At the Croatian Standards Institute the most important CEN standards have been adopted, but, judging by the past practice, their implementation in internal postal traffic will remain on a voluntary basis, although the already mentioned article of the EU Postal Directives explicitly states that the member states have to make sure that the universal service providers are informed about the harmonisation of standards that are published in the EU official gazette, especially when this is in the interest of the customers.

The Directives require the member states to ensure clearly regulated, transparent and inexpensive procedures for resolving of customers' complaints regardless of whether they are providers of universal or other services, i.e. regardless of whether the transfer process involves one or several providers. This allows for just and fast resolving of the claims and compensation payment in case the customer is proved right. Also, the customers have the possibility to start a procedure at the authorised national authorities in case when the claims submitted to the universal service providers have not been resolved in a satisfactory manner. The member states are obliged to make sure that the universal service providers, together with the annual reports on monitoring quality services, publish also the information about the number of submitted complaints and a report regarding their resolving. The Postal Act has adopted normatively this Article of the Directives almost in its entirety.

\subsection{National Regulatory Authority}

The EU Postal Directives (Article 22) obligate every member state to determine one or several national regulatory authorities for postal activities that are legally separate and operatively independent from the postal operators, and to inform the European Commission about the authority that they have appointed to perform the tasks resulting from the Directives. The special task of the national regulatory authorities is to ensure compliance with the obligations pursuant to the Postal Directives, and they may also be in charge of resolving the complaints regarding market competition in postal activities. 
By bringing the Postal Act, the Croatian Parliament established a Council of Postal Services as an autonomous, independent and non-profit legal entity with public authorities funded from the budget. The tasks of the Council have been specified in 12 points, and further in the text only the public authorities that the Republic of Croatia has transferred to the Council are given, and these include:

- issuing of licences for the performance of postal services and adopting resolutions on the expiry of the licence validity,

- determining the amount of the means from the budget from Article 24 of the Act,

- determining the method of separating business activities regarding their accounting systems from Article 25 of the Act,

- resolving of disputes regarding the provision of access to public postal network from Article 26, Item 5 of the Act,

- determining the prices of the reserved postal services, at the proposal of the public operator.

According to EU Postal Directives, the tasks of the national regulatory authority, apart from those as signed to them by the member state, include:

- approval of the wider area of post offices at which receiving and delivery are performed fewer than 5 times a week,

- determining the weight of parcels that refer to universal services and assigning of special conditions that refer to the receiving and delivery of these parcels,

- verifying and monitoring the credibility of the applied method of the separated accountancy system, as described in the Postal Directives by the independent auditing authority,

- possible approval of the implementation of methods of controlling the separation of the accountancy system different from those stipulated by the Directives,

- gathering and monitoring of all the relevant information about the system of controlling the costs of the public universal service provider, and information thereof,

- insuring the performance of independent auditing of the quality of services, determining the credibility of the results and undertaking of corrective measures if the results are unsatisfactory,

- determining the exceptions from standardised quality norms when this is required by the infrastructure or geographic location of a country, and informing thereof the European Commission,

- determining of specific procedures and control in order to make sure the reserved area is complied with.

The final provisions of the EU Postal Directives obligate the Commission to submit reports to the European Parliament and the Council about the im- plementation of the Directives regarding the development of postal activities, particularly those that refer to the economic, social, technological aspects, as well as the employment in the sector and to the sustainable quality of services. It is also stated that the Postal Directives do not prevent any member state to keep or introduce also more liberal measures on its territory.

And finally, it should be emphasised that on 20 February 2008, the European Parliament adopted the Third Postal Directive which entirely liberalises the market of postal services. The member states are obliged to implement the respective Directive by the end of 2010, with the exception of 11 member states that can postpone full liberalisation of the market of postal services until the end of 2012.

\section{CONCLUSION}

It is a fact that in the area of postal services Croatia has partially realised a good level of harmonisation with the EU acquis communautaire. However, there are greater deviations of the Croatian national legislation and the European acquis communautaire regarding the weight/price limits of the reserved area, as well as regarding the provisions on the quality of postal services, furthermore, in the part that refers to the market competition and the privileged status of the universal postal service providers and the competencies of the Council of Postal Services.

Full assessment of the harmonisation of the Croatian legislation with the EU acquis communautaire regarding the postal market will be brought by the European Commission, i.e. by each EU member state during bilateral negotiations with the Republic of Croatia. The paper has presented only some of the uncertainties regarding the Croatian regulatory framework, which has its specific characteristics and which does not follow in its entirety the provisions of the EU Postal Directives. The specifics of the Croatian regulatory framework are reflected, among other things, in the stipulation of the universal services, i.e. postal, courier, other postal, reserved and other services that are sometimes not clear to the providers, customers, regulators and the legislators. These uncertainties are reflected particularly regarding the separation of the postal activities from the related activities, such as logistics, distribution, transport, forwarding, telecommunications, advertising, etc.

With minor lacks of clarity, incorrectness, and inconsistencies, the reserved area has been stipulated in partial compliance with the EU Postal Directives, but it remains unclear what is permitted regarding the self-performance of postal services, whether all the service providers are equal regarding payment of concessions and financial contributions, transparent 
and non-discriminatory access to the public postal network, possibilities of equal entry, i.e. exit from the postal market in the part which has been liberalised and free, whether the customers pay the price based on the actual service cost, especially if they prepare the items so that certain costs of universal service providers are avoided, etc.

The Croatian legal framework has stipulated to the national regulatory authority clear provisions and has left relatively little space for regulatory policy making as stipulated in the EU Postal Directives and as common in the European practice. The stipulation (and classification) of services, establishment of the quality standards of universal services, as well as corrective measures in this respect, harmonisation of technical standards and their inclusion in the postal system, equality of providers on the postal service market, interoperability of the universal service providers as well as other technical and technological, economic and regulatory factors that ensure the consistency and uniqueness of the public postal system, which render the postal services the services of special public importance (Services of General Economic Interest), in Croatia have not been yet completely harmonised with the European regulatory framework.

\section{Mr. SC. PERO TABAK}

E-mail: ptabak@fpz.hr

Vijeće za poštanske usluge

Martićeva 11, 10000 Zagreb, Republika Hrvatska

Dr. sc. SLOBODAN KAŠTELA

E-mail: slobodan.kastela@fpz.hr

Sveučilište u Zagrebu, Fakultet prometnih znanosti

Vukelićeva 4, 10000 Zagreb, Republika Hrvatska

\section{SAŽETAK}

\section{POŠTANSKE DIREKTIVE EUROPSKE UNIJE I HRVATSKI REGULATORNI OKVIR}

U radu su uspoređene Poštanske direktive Europske unije (97/67/EZ i 2002/39/EZ) u pročišćenom tekstu i odgovarajući dijelovi hrvatskog zakonodavnog okvira $u$ cilju harmonizacije nacionalnog poštanskog sustava s europskim. Predstavljeni su predmet propisivanja, vrste poštanskih usluga (posebice univerzalnih), rezervirano područje, potrebni uvjeti za dozvole i prijave, tarifna načela, osiguranje tržišnog natjecanja kroz transparentnost financiranja i razdvajanja računovodstva, poželjna kvaliteta univerzalnih usluga, harmonizacija tehničkih normi te zadaće regulatornog tijela. Kroz predstavljanje pojedinih poglavlja Poštanskih direktiva naznačena su neka specifična rješenja hrvatskog regulatornog okvira te dvojbe koje proističu iz usporedne analize europskih Poštanskih direktiva i hrvatskog zakonodavstva kao i utjecaj tih dokumenata na tehnologiju poštanskog prometa.

\section{KLUUČNE RIJEČI}

Poštanske direktive EU, hrvatski poštanski regulatorni okvir, univerzalne usluge

\section{REFERENCES}

1. This phase is called screening, i.e. analysis and assessment of the national legislation of an accession country compared with the EU acquis communautaire

2. National Gazette No. $53 / 94$

3. National Gazette No. $172 / 03,92 / 05$

4. National Gazette No. 151/04, 122/05

5. Conventions on unifying certain rules for international air transport, Montreal, 1999

6. LC (standardised, machineable postal items) AO (nonstandardised postal items)

\section{LITERATURE}

\section{Croatian Acts:}

[1] Zakon o pošti (Postal Act), Narodne novine br. (Official Gazette No.) 53/94

[2] Zakon o pošti, (Postal Act) Narodne novine br. (Official Gazette No.) 172/03, 15/04. ispr. (Corr.) 92/05

[3] Pravilnik o poštanskom sustavu javnog operatora, (Regulations on Public Operator Postal System), Narodne novine br. (Official Gazette No.) 5/05

[4] Pravilnik o općim uvjetima za obavljanje poštanskih usluga, (Regulations on General Conditions for Performing Postal Services), Narodne novine br. (Official Gazette No.) 151/04, 122/05

[5] Pravilnik o naknadi za dozvolu za obavljanje univerzalnih poštanski usluga, (Regulations on Fee for Licence to Perform Universal Postal Services), Narodne novine br. (Official Gazette No.) 20/04

[6] Odluka o visini i načinu korištenja naknade koju plaćaju davatelji univerzalnih poštanskih usluga iz prihoda ostvarenog $u$ prethodnoj godini, (Decision on the amount and method of using fees paid by universal postal service providers from the revenue realised in the previous year), Narodne novine br. (Official Gazette No.) 2/05

[7] Pravilnik o mjerilima i kriterijima te postupku za ostvarivanje prava na podmirenje troškova javnog operatora iz sredstava državnog proračuna, (Regulations on measures and criteria and the procedure to realise the rights to settle the costs of the public operator from the budget means), Narodne novine br. (Official Gazette No.) $16 / 05$

[8] Izvješće o analitičkom pregledu Hrvatska (Report on Analytic Overview Croatia), Poglavlje 3 (Chapter 3) Sloboda pružanja usluga (Freedom of Service Provision), MVPEI, 2005

\section{European Documents:}

[9] Green Paper on the Development of the Single Market for Postal Services (COM/91/476)

[10] Council Resolution of 7 February 1994 on the Development of Community Postal Services (COM/93/247)

[11] $1^{\text {st }}$ Postal Directive $(97 / 67 /$ EC) 
[12] Notice from the Commission on the Application of the Competition Rules the Postal Sector and on the Assessment of certain State measures relating to postal services (98/C39/02)

[13] $2^{\text {nd }}$ Postal Directive (2002/39/EC)

[14] $1^{\text {st }}$ Commission Report to the European Parliament and the Council on the application of the Postal Directive (COM/2002/632)

[15] $2^{\text {nd }}$ Commission Report to the European Parliament and the Council on the application of the Postal Directive (COM/2005/102)

[16] Proposal for the directive of the European Parliament and of the Council amending Directive 97/67/EC concerning the full accomplishment of the internal market of community postal services - COM/3006/594 final

[17] $3^{\text {rd }}$ Postal Directive (2008/6/EC)

\section{European Studies}

[18] The impact on Universal service of the full market accomplishment of the postal internal market in 209 (PricewaterhouseCoopers - May 2006)

[19] Main developments in the postal sector (2004-2006) - (WIK Consult GmbH - May 2006)

[20] Study on the evolution of the regulatory model for European postal service (Wik Consult - July 2005)
[21] Study on the development of competition in the European postal sector (Ecorys - July 2005)

[22] Study about the economics of postal services (NERA - July 2004)

[23] Study of the Relationship between the Constitution, Rules and Practice of the Universal Postal Union (UPU), the Rules of the World Trade Organisation (WTO), in particular the GATS (General Agreement on Trade in Services), and European Community (EC) Law (TMC Asser Institute - July 2004)

[24] Quality of Service Objectives, Performance and Measurement in relation to Community Universal Postal Service (August 2003)

[25] Study on the cost accounting systems of providers of the universal postal service (CTcon, July 2001)

[26] Study on the conditions governing access to universal postal services and networks (CTcon, July 2001)

\section{World Documents}

[27] Letter post manual, UPU, Bern, 2005

[28] Parcel post manual, UPU, Bern, 2005

[29] General Agreement on Trade in Services (GATS), WTO, 2000 